\title{
PENERAPAN MODAL SOSIAL DALAM PRAKTEK PERADILAN YANG BERBASIS KEPEKAAN SOSIAL
}

\author{
Zaka Firma Aditya \\ Pusat Penelitian dan Pengkajian Perkara, Mahkamah Konstitusi Republik Indonesia \\ Jalan Medan Merdeka Barat Nomor 6, Jakarta Pusat \\ Email : zaka.aditya@gmail.com
}

\begin{abstract}
The judiciary is an institution that should reflect on justice sought by justice seekers. But the fact is different; justice becomes one of the institutions with a high level of public distrust. The actual social capital has been present and is present in the community but has not yet been functioned and used further, especially by law enforcement officers making law enforcement in Indonesia far from expectations. In fact, the concept of modern justice has been triggered at international meetings that not only prioritize formal legal aspects but also the intellectual, emotional and spiritual aspects of law enforcement as well as social capital. In an effort to bring about a legal state with progressive legal practice will greatly depend not only on good legislation but much more dependent on law enforcement officials as implementers of the law
\end{abstract}

Keywords: Social Capital, Reform, Community, Law, Judicature

\begin{abstract}
Abstrak
Peradilan merupakan lembaga yang seharusnya merefleksikan keadilan yang selama ini dicari-cari oleh para pencari keadilan. Namun faktanya berbeda, justru peradilan menjadi salah satu lembaga dengan tingkat ketidak percayaan masyarakat yang cukup tinggi. Modal sosial yang sebenarnya selama ini ada dan hadir di masyarakat namun belum banyak difungsikan dan dimanfaatkan lebih jauh, terutama oleh aparat penegak hukum menjadikan penegakkan hukum di Indonesia jauh dari harapan. Padahal, Konsep peradilan modern telah dicetuskan di pertemuan Internasional yang tidak hanya mengedepankan aspek legal formal namun juga aspek intelektual, emosional dan spiritual penegak hukum termasuk pula social capital. Sebagai upaya mewujudkan negara hukum dengan praktek hukum yang progresif akan sangat tergantung bukan hanya para perundang-undangan yang baik tapi jauh lebih tergantung lagi pada aparat penegak hukum sebagai pelaksana undang-undang tersebut.
\end{abstract}

\section{Kata Kunci: Modal Sosial, Reformasi, Masyarakat, Hukum, Peradilan}

\section{A. PENDAHULUAN}

Kegelisahan mengenai tata kerja kekuasaan kehakiman (judicative power) di Indonesia sudah lama diperbincangkan dan dipersoalkan baik oleh masyarakat maupun oleh para pakar hukum. Hal ini diakibatkan karena adanya nilai-nilai keadilan (justice) masyarakat yang terus terbelenggu dengan banyaknya praktek mafia yang berlangsung disekitar lembaga peradilan. Sebuah pameo latin kuno telah menggambarkan mengenai betapa mulianya sebuah lembaga peradilan. Pengadilan dipandang sebagai "nec curia defi ceret in justitia exhibenda" (pengadilan adalah istana di mana dewi keadilan bersemayam untuk menyemburkan aroma 
keadilan tiada henti). Pameo ini sejatinya mencoba merefleksikan eksistensi dunia peradilan yang teramat mulia, berwibawa dan tempat bersemayamnya prinsip-prinsip keadilan. Apalagi para hakim ketika mengadili dan memutus perkara harus menjelmakan dirinya dan bertindak sebagai "wakil tuhan" di muka bumi. Beban moral ini sangat berat karena pertanggungjawabannya bukan hanya secara horizontal kepada sesama manusia, tetapi juga tanggung jawab secara vertikal kepada Tuhan, maka hal Ini merupakan sisi lain yang harus dipertaruhkan sebagai seorang hakim. Kekuasaan kehakiman (judicative power) memang menjadi harapan terakhir bagi para pencari keadilan.

Akan tetapi, ekspektasi lembaga peradilan sebagai lembaga yang mulia dan berwibawa ini nampaknya mulai dipertayakan ketika menyaksikan drama peradilan yang rusak dicederai oleh perilaku praktek-praktek kecurangan. Meskipun pengawasan telah dilakukan super ketat baik oleh lembaga negara yang diberikan kewenangan secara khusus mengawasi proses peradilan maupun lembaga independen, namun kenyataannya masih terdapat banyak celah yang terbuka dan longgar di insitusi peradilan yang bisa disusupi oleh praktek-praktek licik, kotor dan curang. Kondisi tersebut berbanding terbalik dengan bentuk slogan prinsip institusi yang mengedepankan moralitas yang selalu diteriakan dengan nyaring oleh para penegak hukum dan dipandang cukup mulia, justru berubah hanya menjadi nyanyian kosong. Moralitas hanya digunakan sebagai topeng dan kedok berjubah untuk melakukan penyusupan dan sekaligus sebagai pembenaran atas putusan-putusannya. Pada konteks ini, mungkin ada benarnya apa yang dikatakan oleh Jeremy Bentham, ${ }^{1}$ bahwa para aparat penegak hukum adalah segerombolan orang yang dapat mengangkangi hukum tanpa konsekuensi hukum. Pada sisi inilah kekuasaan kehakiman tampil sebagai sebuah cermin yang retak karena belum mampu merekatkan nilai-nilai keadilan masyarakat yang masih berserakan.

Persoalan mengenai buruknya praktek mafia di lembaga peradilan sebetulnya sudah lama berlangsung. Bahkan para pakar kriminolog pernah melakukan penelitian mengenai penyimpangan dalam dunia peradilan. William J. Chamblis dan Robert B. Seidman dalam bukunya yang berjudul "Law, Order, and Power", menuliskan bahwa kebengkokan itu sudah dimulai dari segi hukumnya, yakni karena adanya hukum yang menjadi refleksi dari kepentingan kelompok elite yang berkuasa (the higher a group's political and economic position). ${ }^{2}$ Bahkan keduanya mempertegas bahwa penyimpangan dalam dunia peradilan terjadi karena "judges must rely on their personal values when they make decisions in trouble cases". ${ }^{3}$ Sisi lain yang paling potensial melahirkan kejahatan (judicial crime), yakni adanya kecenderungan serta upaya hakim meraup kekayaan dan kekuasaan dari pekerjaan yang diembannya.

Sementara itu, Global Corruption Report 2007 yang diluncurkan oleh Transparency International, sebuah koalisi global antikorupsi memilih thema Corruption in Judicial Systems. Korupsi dianggap melumpuhkan sistem yudisial di seluruh dunia serta menghalangi hak asasi manusia akan peradilan yang adil dan tidak berpihak. Huguette Labelle, ketua

\footnotetext{
${ }^{1}$ Budi Gunawan, Koloni Keadilan; Kumpulan Analisis di Majalah Forum, Forum Media Utama, Jakarta: 2006, hlm. 13.

${ }^{2}$ Ibid.

${ }^{3}$ Ibid.
} 
Transparency International menegaskan dengan adanya korupsi lembaga peradilan, mereka yang berada di pihak yang benar kehilangan hak didengar sedangkan yang bersalah tidak tersentuh hukum. Uang serta pengaruh politik dalam hukum memecah sistem keadilan sosial: satu sistem bagi si kaya, pada sisi lain bagi si miskin. "Jika uang dan pengaruh politik menjadi dasar keadilan, mereka yang miskin tidak dapat berkompetisi. ${ }^{4}$

Relevansi Indonesia yang dilaporkan Global Corruption Report 2007 telah menunjukkan bahwa sistem peradilan di Indonesia masih sangat korup dan rusak. Hal ini sangat relevan dengan hasil Indeks Persepsi Korupsi (IPK) Indonesia 2006 yang dirilis oleh Transparency International (TI) Indonesia. Survey IPK itu menemukan bahwa lembaga vertikal (Polisi, Peradilan, Pajak, BPN, Imigrasi, Bea \& Cukai, Milter dan lain-lain) masih dipersepsikan sangat korup. Lebih memalukan lagi, mereka dengan terbuka melakukan upaya korupsi secara langsung meminta suap, hal ini dikonfirmasikan oleh laporan para pelaku usaha bahwa inisiatif suap lebih banyak dilakukan oleh aparat. Pengadilan dilaporkan merupakan lembaga yang paling tinggi tingkat inisiatif meminta suap hingga 100\%, disusul Bea dan dan cukai 95\%, Imigrasi 90\%, BPN 84\%, Polisi 78\%, dan Pajak 76\%. Dua katagori korupsi peradilan yakni campur tangan politik dan penyuapan juga sangat jelas terlihat. ${ }^{5}$

Daniel Kaufman dalam laporan Bureaucratic Judiciary Bribery tahun 1998 menyebutkan, korupsi di peradilan Indonesia memiliki ranking paling tinggi di antara negara-negara seperti Ukraina, Venezeula, Rusia, Kolombia, Mesir, Yordania dan Turki. Bahkan, hasil survei nasional tentang korupsi yang dilakukan Partnership for Governance Reform pada 2002 juga menempatkan lembaga peradilan di peringkat lembaga terkorup menurut persepsi masyarakat. Hal tersebut diperkuat dengan laporan Komisi Ombudsman Nasional (KON) tahun 2002, bahwa berdasarkan pengaduan masyarakat menyebutkan penyimpangan di lembaga peradilan menempati urutan tertinggi, yakni $45 \%$ dibandingkan lembaga lainnya. Bahkan data terakhir yang dilansir Komisi Yudisial menyebutkan bahwa 2.440 hakim atau sekitar 40 persen dari total 6.100 hakim dikategorikan bermasalah, yang pada akhirnya membuat praktek hukum diwarnai judicial corruption. Realita sistem hukum dan peradilan di negeri ini, nampaknya tergambarkan dalam penelitian yang dilakukan oleh The Asia Foundation \& AC Nielsen yang antara lain menyatakan: $49 \%$ sistem hukum tidak melindungi mereka (the legal system does not protect them), 38\% tidak ada persamaan di muka hukum (there is no such thing as equality before the law), 57\% sistem hukum masih tetap korup (the legal system is just as corrupt as it has always been problem). ${ }^{6}$

Lebih jauh, dengan keluarnya Keputusan Mahkamah Agung KMA No 144/SK/KMA/ VIII/2007 tentang Keterbukaan Informasi Peradilan menjadi salah satu tonggak sejarah penting yang menandai kuatnya semangat lembaga peradilan di Indonesia untuk terus mereformasi institusi ruang kehakiman, khususnya dalam menyongsong era transparansi yang semakin menjadi tren global.

Dalam skala internasional, langkah ini juga menemukan momentum yang tepat, misalnya melalui Court Quality Forum yang berlangsung di Sydney, Australia pada tanggal 21-23

\footnotetext{
${ }^{4} \mathrm{http}: / /$ www.ti.or.id (diakses pada 17/011/2017).

${ }^{5}$ Ibid.

${ }^{6}$ Diedit dari http://ahmadrifan.wordpress.com (diakses pada 16/01/2018).
} 
September 2008. Nilai-Nilai dasar (core values) yang merupakan hasil kesepakatan negaranegara yang hadir dalam acara internasional tersebut merupakan prinsip-prinsip nilai lembaga peradilan yang menjadi target pencapaian institusional. ${ }^{7}$ Terlebih lagi kesepuluh nilai-nilai dasar ini kemudian diterjemahkan pada tujuh area implementasi yang tidak lain merupakan wilayah-wilayah terpenting performa lembaga peradilan sebagai tumpuan dan harapan masyarakat pencari keadilan. ${ }^{8}$

Dalam rangka mengoptimalisasikan upaya merealisasikan target-target reformasi peradilan, modernisasi peradilan merupakan salah satu visi yang dirumuskan secara kelembagaan. Belajar dari pengalaman berbagai negara yang sukses dalam program judicial reform, modernisasi peradilan diyakini sebagai metode terbaik yang harus terus dimaksimalkan ${ }^{9}$. Untuk mewujudkan modernisasi ini. dibutuhkan formula-formula yang diharapkan dapat mengakselerasi implementasi program modernisasi peradilan tersebut. Diantara formulasi tersebut adalah melalui fungsionalisasi modal sosial (social capital) sebagai instrumen penting dalam praktek penegakkan hukum berbasis kepekaan sosial sehingga keadilan yang selama ini dicari-cari oleh para pencari keadilan akan terlebih lebih jelas dan berpihak. Berdasarkan latar belakang tersebut, penulis ingin meneliti terkait bagaimanakah modal sosial (social capital) dapat memberikan kontribusi aktif dalam merubah perilaku ketidakpatutan dalam lingkup ruang peradilan.

\section{B. PEMBAHASAN}

\section{Teori Social Capital}

Mendahului pembahasan lebih jauh tentang modal sosial, sekiranya penting terlebih dahulu dipaparkan konsep dari modal sosial. Menurut Pierre Bourdieu (1986) modal sosial tidak kurang dari suatu jaringan hubungan yang tidak given secara alamiah maupun sosial, tapi merupakan sesuatu yang harus dikerjakan. Modal sosial merupakan hasil investasi strategis dari individu maupun kolektif yang secara sadar atau tidak sadar diperoleh dari produk hubungan-hubungan sosial yang secara langsung dapat digunakan. Atas dasar itu, Bourdieu mentasrifkan modal sosial sebagai,"...the aggregate of the actual or potential resources which are linked to.... membership in a group - which provides each of its members

\footnotetext{
${ }^{7}$ Hasil dari Court Quality Forum yang berlangsung di Sydney, Australia, tanggal 21-23 September 2008. Sepuluh nilai-nilai dasar (core values) tersebut adalah: (1) perilaku yang sama di depan hukum (equality before the law), (2) Kejujuran (fairness), (3) tidak memihak (impartiality), (4) kebebasan dalam membuat keputusan (independence of decision making), (5) kemampuan (competence), (6) berintegritas (integrity), (7) terbuka (transparency), (8) mudah dikunjungi (accessibility), (9) tepat waktu (timeliness), (10) kepastian (certainty). ${ }^{8}$ Sepuluh nilai-nilai dasar (core values) ini selanjutnya diterjemahkan menuju upaya menciptakan kerangka sistem peradilan yang terbaik yang digambarkan dalam Seven Areas for Court Excellence yaitu: 1) Kepemimpinan dan Manajemen Peradilan (Court Management and Leadership), 2) Kebijakan Pengadilan (Court Policies), 3) Sumber Daya Pengadilan yaitu: Personil, Materil, dan Keuangan (Human, Material, and Financial Resources), 4) Proses Persidangan (Court Proceeding), 5) Kepuasan Pencari Keadilan (Client Needs and Satisfaction), 6) Biaya Terjangkau dan Akses ke Pengadilan (Affordable and Accessible Court Service), dan 7) Kepercayaan Masyarakat (Public Trust and Confidence).

${ }^{9}$ Salman, IESQ Based Court Modernization: Menuju Peradilan Modern Berbasis Kecerdasan Intelektual, Emosional, dan Spiritual, Pengadilan Agama Cilegon, Banten: 2009, hlm. 2.
} 
with the backing of the collectivity owned capital." ${ }^{10}$ Bourdieu pada dasarnya lebih menekankan pada jaringan-jaringan sosial yang menyediakan akses pada sumber daya sebuah komunitas atau kelompok. Di dalam pemahaman Bourdieu, modal sosial merupakan bagian dari konsep yang dalam dirinya mewakili tiga arti mendasar.

First, as economic capital, which is immediately convertible into money and may be institutionalised in the form of property rights. Second, as cultural capital, which is convertible, on certain conditions, into economic capital and may be institutionalised in the form of educational qualifications. Third, as social capital, made up of social obligations ('connections'), which is convertible, in certain conditions, into economic capital and may be institutionalised in the form of a title of nobility. ${ }^{11}$

Sedikit berbeda dengan Bourdieu, James Coleman memberi penekanan pada ketersediaan sumber daya yang dalam struktur sosial tanpa merinci wujud nyata dari modal sosial dimaksud. Hal ini tampak dari konsepnya tentang modal sosial sebagai, "...a variety of different entities, with two elements in common: they all consist of some aspect of social structure, and they facilitate certain actions of actors-whether personal or corporate actors-within the structure". ${ }^{12}$

Memang, Coleman lebih memberi perhatian pada fungsi dan manfaat modal sosial itu sendiri ketimbang unsur-unsur spesifiknya. Ia mengatakan,"... social capital is defined by its function. It is not a single entity but many entities with two elements in common: 1) they all consist of some aspect of social structures; 2) they facilitate certain actions of actors within the structure. ${ }^{13}$ Coleman lebih lanjut menegaskan bahwa "the function identified by the concept of 'social capital' is the value of these aspects of social structure to actors as resources that they can use to achieve their interests". ${ }^{14}$

Pakar kunci lainnya yang mengupayakan kerja sistematis bagi konseptualisasi istilah modal sosial adalah Robert D. Putnam. ${ }^{15}$ Meskipun Putnam melakukan operasionalisasi konsep modal sosial ke dalam skala sosial yang berbeda dengan konsep Bourdieu dan Coleman, namun haruslah diakui bahwa operasionalisasi konsep modal sosialnya diturunkan dari konsep Coleman. Putnam mendefinisikan modal sosial sebagai jaringan-jaringan, nilainilai, dan kepercayaan yang timbul di antara para anggota komunitas; yang fungsinya memfasilitasi koordinasi dan kerja sama untuk manfaat bersama (trust, norms, and networks'

\footnotetext{
${ }^{10}$ Pierre Bourdieu, The Forms of Capital, Handbook of Theory and Research for the Sociology of Education, New York-Greenwood: 1986, hlm. 241-258.

${ }^{11}$ Ibid.

12 World Bank, The Initiative on Defining, Monitoring, and Measuring Social Capital, Overview and Programme Description, Working paper, No. 1, 1998, http://www.worldbank.org/poverty/scapital/wkrppr/sciwp1.pdf , (diakses pada 17/01/2018).

${ }^{13}$ James S. Coleman, Social capital in the Creation of Human Capital, American Journal of Sociology, vol. 94, 1998, hlm. 95-120.

${ }^{14}$ Ibid., hlm. 101.

${ }^{15}$ Robert D. Putnam, Making Democracy Work: Civic Traditions in Modern Italy, Princeton University Press, Princeton: 1993. Juga terdapat dalam, Robert D. Putnam, The Prosperous Community: Social Capital and Public Life, The American Prospect, Spring, 1993a, hlm. 35-42. Robert D. Putnam, The Strange Disappearance of Civic American', policy, autumn, 1996, hlm. 3-15. Robert D. Putnam, Foreword, housing Policy Debate, No. 1, Vol. 9, 1998, hlm. v-viii.
} 
that facilitate cooperation for mutual benefit $)^{16}$.

Dalam pandangan Putnam, modal sosial terkait dengan seperangkat "perkumpulanperkumpulan horisontal" yang ada dalam masyarakat di mana modal sosial terdiri atas jaringan kerja sosial, dan norma-norma yang diasosiakan dengannya yang memberikan pengaruh pada produktifitas masyarakat. Selengkapnya Putnam menyatakan bahwa modal sosial adalah, "... a set of "horizontal associations" between people: social capital consists of social networks ("networks of civic engagement") and associated norms that have an effect on the productivity of the community". 17 Karena modal sosial merupakan seperangkat perkumpulan-perkumpulan horisontal yang terdiri atas kepercayaan, norma-norma, dan jaringan-jaringan yang dapat memfasilitasi kerja sama bagi keuntungan bersama, maka fungsi modal sosial tidak lain daripada instrumen yang memfasilitasi koordinasi dan kerja sama dalam rangka keuntungan bersama dari anggota-anggota perkumpulan/komunitas.

Terhadap kerangka Putnam, Tay Keong Tan, mengelaborasi 3 (tiga) indikator penting dari modal sosial, yaitu: (1) saluran-saluran informasi dalam suatu komunitas, (2) Struktur otoritas, dan (3) kondisi batas. Saluran informasi berfungsi sebagai jaringan pertukaran ide, aspirasi dan perasaan antarindividu anggota komunitas; sementara struktur otoritas berfungsi untuk memelihara ketertiban dan stabilitas, di samping sebagai alat pengawasan atas kegiatan para anggota. Tapal batas yang dimaksudkan Putnam, lebih kepada status individu dalam mengekspresikan loyalitas dan kesepakatan. Bentuknya, dapat berupa batas-batas kultural, simbol-simbol dan praktik-praktik yang membedakan dari yang lain. ${ }^{18}$

Kerja sama sebagai kata kunci modal sosial dikemukakan pula oleh Francis Fukuyama yang mengartikan modal sosial sebagai, “...an instantiated informal norm that promotes cooperation between two or more individuals". ${ }^{19}$ Dalam jalinan kerja sama itu menurut Fukuyama $^{20}$ akan muncul saling mempercayai, untuk selanjutnya kepercayaan antaranggota komunitas berfungsi ibarat pelumas yang membuat jalannya komunitas atau organisasi menjadi lebih efisien. Norma yang menentukan modal sosial dalam terminologi Fukuyama sangat luas. Mulai dari aturan yang mengatur hubungan dua orang teman hingga ke aturan yang dielaborasi dalam doktrin-doktrin keagamaan. Sementara itu, dalam pemahaman Bank Dunia (1999), modal sosial menunjuk pada berbagai institusi, hubungan, dan norma yang menentukan mutu dan tingkat sosialitas hubungan-hubungan sosial dalam masyarakat. ${ }^{21}$

Dengan demikian modal sosial merupakan sebuah proses dalam komunitas yang terdiri atas beberapa unsur mendasar. Pertama, adanya jaringan sosial (keterlibatan para anggota kelompok). Kedua, adanya nilai bersama. Ketiga, adanya aturan-aturan bersama. Keempat, adanya pertemanan (pertetanggaan) atau solidaritas sosial (kohesi sosial). Keenam, adanya

\footnotetext{
${ }^{16}$ Robert D. Putnam, Civic Traditions in Modern Italy, Ibid., hlm. 167.

17 Ibid., hlm. 171.

${ }^{18}$ Tay Keong Tan, Modal Sosial dan Lembaga-Lembaga Legislatif, dalam Panduan Parlemen Indonesia, Yayasan Api, Jakarta: 2001, hlm. 65-67.

${ }^{19}$ Francis Fukuyama, Social Capital and Civil Society, Paper, Prepared for Delivery at the IMF Conference on Second Generation Reforms, The Institute of Public Policy George Mason University, 1999, http://www.imf.org/external/pubsft/seminar/1999/reforms/fukuyama.htm, (diakses pada 18/01/2018).

${ }^{20}$ Francis Fukuyama, 1999., The Great Disruption ....Op cit., hlm. 22.

${ }^{21}$ K. Smith, Social Capital, 2000, http://www.infed.org/biblio/social capital, (diakses pada 19/01/2018).
} 
koordinasi dan kerja sama. Ketujuh, adanya tujuan bersama yakni mutual benefit. ${ }^{22}$ Jelas kiranya bahwa modal sosial merupakan sebuah kebutuhan bagi terciptanya kerja sama yang produktif dalam suatu masyarakat, kelompok, komunitas, ataupun suatu asosiasi.

Modal sosial merupakan bagian dari komunitas atau entitas sosial. Sebuah komunitas atau entitas sosial, disadari atau pun tidak disadari, memiliki apa yang disebut dengan modal komunitas (community capital. Secara umum modal komunitas ini meliputi 4 (empat) elemen mendasar, yakni: human capital, produced economic capital, natural capital, dan social capital.

Modal manusia (human capital) sebuah komunitas menyangkut kemampuan sumberdaya manusia atau kemampuan personal anggota komunitas, meliputi: pendidikan, pengetahuan, keahlian, kesehatan, dan keadaan terkait lainnya. Modal ekonomi (produced economic capital) menyangkut suberdaya ekonomi, meliputi: ketersediaan asset-asset ekonomi, kemampuan finansial, dan daya dukung ekonomi lainnya yang berhubungan dengan kemampuan pembiayaan. Modal alami atau sumberdaya alam (natural capital) menyangkut daya dukung alamiah yang dimiliki sebuah komunitas, berupa ketersediaan sarana dan prasarana yang mendukung kelangsungan hidup komunitas secara alami. Modal sosial (social capital) menyangkut jaringan interrelasi abtrak berupa nilai-nilai, norma-norma, jaringanjaringan sosial, partisipasi dalam kelompok, dan proactivity.

Semua modal komunitas (community capital) tersebut, selain mempunyai peran dan fungsinya sendiri-sendiri, juga antara modal komunitas yang satu dengan yang lain tidak dapat dilepas-pisahkan. Unjuk kerja atau pun kelangsungan hidup sebuah komunitas sematamata tidak dapat digantungkan pada salah satu saja dari sejumlah modal komunitas tersebut. Idealnya, semua modal komunitas diberdayakan, karena peran-peran positif semua modal komunitas itulah yang menentukan kelangsungan hidup sebuah komunitas. Secara skematis interrelasi antara community capital tersebut dalam menunjang kelangsungan hidup sebuah komunitas adalah sebagai berikut: ${ }^{23}$

${ }^{22}$ Ibid.

${ }^{23}$ Disadur dari berbagai sumber dengan mempedomani skema Jousairi Hasbullah, Ibid. hal.18. 


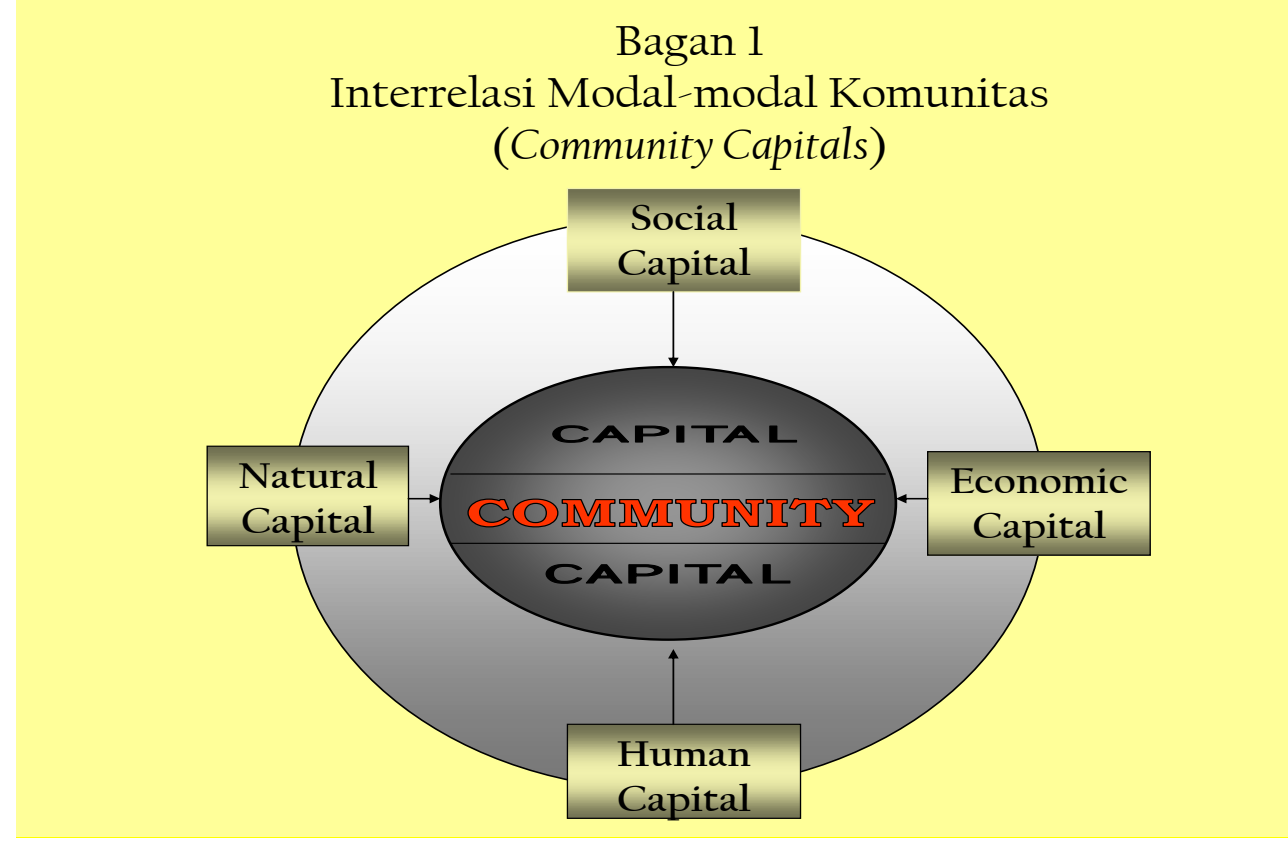

Gambar 1. interrelasi modal-modal komunitas (community capital)

Khusus tentang modal sosial sebagai salah satu dari 4 (empat) modal komunitas tersebut di atas, dalam konstelasi teori sosial, merupakan konsep teori yang telah lama diperbincangkan. Teori modal sosial (social capital) adalah konsep lama yang di revieuw kembali, tepatnya ketika pada tahun 1997 Francis Fukuyama membawanya ke dalam perspektif pembangunan ekonomi dan peradaban bangsa.

Modal sosial adalah perekat untuk saling percaya (trust) atau dalam konteks lebih lebar merujuk pada sumber daya, informasi, gagasan, dan dukungan bagi individu untuk berperan dan berinteraksi dalam kelompok sosial. Modal sosial adalah hakikat dan derajat keterlibatan individu dalam jaringan informal dan suatu organisasi formal, sehingga menjadi suatu perekat yang merajut kelompok dan masyarakat, termasuk di dalamnya nilai hidup, norma dan kelembagaan aturan main yang dijunjung tinggi dan dihormati bersama. ${ }^{24}$ Secara skematis peran modal sosial, interrelasinya dengan faktor internal atau eksternal dan luarannya, menurut perspektif teori modal sosial adalah sebagaimana tampak pada bagan berikut:

${ }^{24}$ Tom schuller, The Complementary Roles, Ibid. 


\section{Bagan 2 \\ Peran Modal Sosial, Interrelasinya dengan \\ Faktor Internal/Eksternal Komunitas dan Luarannya}

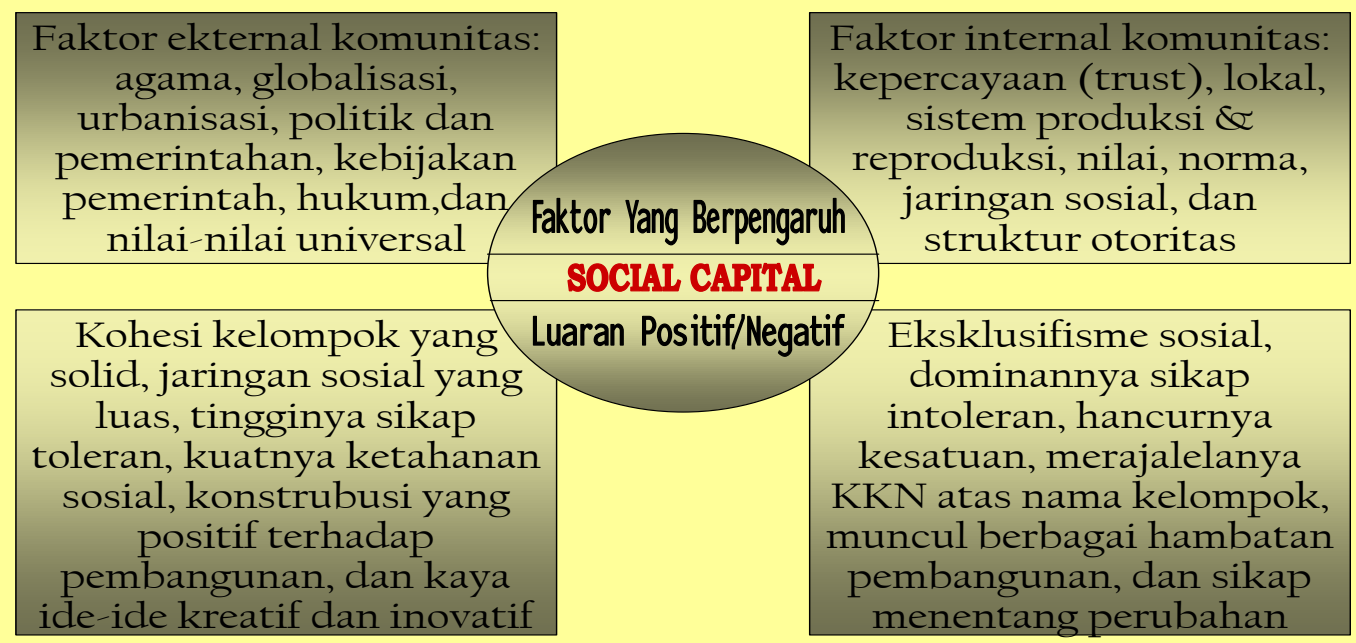

Gambar 2. Peran Modal Sosial, Interelasinya dengan faktor Internal/eksternal Komunitas dan Luarannya

Cukup banyak hipotesis berkembang dari konsep modal sosial ini, mulai dari keterkaitan antar individual dalam sistem sosial secara horisontal dan secara vertikal dengan jenjang, hierarki, atau strata sosial tertentu. Ekonom umumnya memperlakukan modal sosial dalam perspektif bonding dan bridging. ${ }^{25}$

Modal sosial bonding merujuk pada penumbuhan trust dan network yang bernuansa "ke dalam" karena kesamaan demografis seperti keluarga, marga, suku, keterikatan emosional, alumni, kolega dan sebagainya. Modal sosial bridging lebih berupa trust yang tumbuh dan berkembang dengan nuansa "ke luar" dalam suatu kesamaan nilai atau tujuan, sampai pada aturan-aturan dalam organisasi, perkumpulan tertentu dan bahkan sampai skala negara. $^{26}$

Modal sosial secara sedehana dapat diartikan sebagai seperangkat perkumpulan horisontal yang terdiri atas kepercayaan, nilai dan norma-norma, jaringan-jaringan sosial, dan struktur otoritas, yang berfungsi memfasilitasi kerja sama dalam komunitas sosial. Dalam skema teori modal sosial, keseluruhan unsur modal sosial tersebut merupakan daya internal yang dimiliki sebuah komunitas untuk mengatasi bersama masalah yang dihadapi. Titik sentral modal sosial menurut Cohen dan Prusak adalah pada apa disebut sebagai make cooperative action possible. ${ }^{27}$

Kepercayaan yang kemudian terwujud dalam bentuk kerja sama atau integrasi, merupakan kata kunci mutu modal sosial suatu komunitas, yang ditandai oleh: (1) adanya ikatan saling percaya, (2) adanya jaringan komunikasi yang memungkinkan terciptanya

\footnotetext{
${ }^{25}$ Penjelasan yang relatif lengkap perihal modal sosial dalam perspektif bonding dan bridging ini; baca dalam, Christian Grootaert, "Social Capital, Hauseholf Welfare, and Proverty in Indonesia", Policy Research Working Paper 2148, World Bank, Washington D.C. : 1999.

${ }^{26}$ Ibid.,

${ }^{27}$ K. Smith, Social Capital, 2000, dalam http://www.infed.org/biblio/social capital, disadur 25 Mei 2004.
} 
hubungan dialogis, (3) adanya nilai bersama yang memungkinkan terciptanya orientasi bersama, di mana norma sebagai aturan mainnya, dan (4) adanya struktur otoritas yang dihormati bersama.

Dalam perspektif Parsonian, itu berarti mutu modal sosial sangat ditentukan oleh ada tidaknya kesepakatan nilai, kesepakatan norma, dan kesepakatan struktur. Kesepakatan berdimensi nilai ditandai oleh adanya "pola bersama" tentang apa yang benar, baik, dan luhur yang dianggap cukup mulia untuk dipertahankan. Sedangkan kesepakatan berdimensi norma ditandai oleh adanya standar aturan main bersama, dan kesepakatan berdimensi struktur ditandai oleh adanya otoritas struktur yang dipercaya sebagai resolusi konflik. Menurut Parsons $^{28}$, setidaknya ada 3 (tiga) bentuk nilai dalam suatu komunitas, yakni: (1) cognitive, yakni nilai standar tentang tujuan yang ingin dicapai. Ukurannya adalah, "baik-buruk", (2), appreciative, yakni nilai tentang standar penghargaan. Ukurannya adalah pantas-tidak pantas, dan (3) moral, yakni nilai tentang yang benar atau yang salah.

Motif-motif dan nilai-nilai ${ }^{29}$ tersebut menimbulkan bentuk-bentuk tindakan, yang juga berbeda-beda, yakni instrumental bagi tindakan untuk merealisir tujuan secara efisien; ekspresif untuk kategori tindakan yang dilakukan demi mendapatkan kepuasan emosional semata; dan moralitas bagi tindakan yang menyangkut prinsip benar atau salah. Tindakan mana yang akan diambil sangat ditentukan oleh jenis motif dan nilai yang mendominasi pertimbangan seseorang. ${ }^{30}$

Menurut Theodore Steeman, nilai dan norma bersama dalam suatu komunitas merupakan unsur paling mengemuka dari fenomena komunitas sebagai sebuah struktur yang terintegrasi $^{31}$. Karena itu, untuk mempertahankan keutuhan dan mencapai tujuan suatu komunitas tiap anggota dituntut mengintegrasikan diri di bawah nilai dan norma yang menjadi kerangka normatif bersama. Kehidupan bersama hanya dapat dijalankan apabila anggotaanggotanya bersedia mematuhi dan mengikuti aturan main bersama yang telah ditentukan ${ }^{32}$. Prinsip dasar ini, menurut Parsons, bersifat umum dan mengendalikan semua tipe tingkah laku manusia lintas budaya ${ }^{33}$.

Inti modal sosial terletak pada bagaimana kemampuan masyarakat dalam suatu entitas atau kelompok untuk bekerjasama membangun suatu jaringan untuk mencapai tujuan bersama kerjasama. Ia dibangun atas norma-norma dan nilai-nilai sosial yang positif dan kuat, kekuatan mana akan maksimal jika didukung oleh semangat proaktif membuat jalinan hubungan di atas prinsip-prinsip sebaga berikut: ${ }^{34}$

a. Partsipasi dalam suatu jaringan Dalam Suatu Masyarakat

\footnotetext{
${ }^{28}$ Jonathan Turner, The Structure of Sociological Theory, ILL: The Dorsey Press, Chicago: 1986, hlm.. 61.

${ }^{29}$ Robert N. Bellah, Religi Tokugawa: Akar-akar Budaya Jepang, Terjemahan W. Hafidz, Karti Sarana \& Gramedia, Jakarta: 2002, hlm. 5.

${ }^{30}$ Turner, The Structure..., Op.Cit., hlm. 75.

${ }^{31}$ Theodore M. Steeman, Religious Pluralism and National Integration, Disertation, Harvard University, Massachussets, 1973, hlm. 14.

${ }^{32}$ Eka Darmaputera, Pancasila Identitas dan Modernitas: Tinjauan Etis dan Budaya, BPK Gunung Mulia, Jakarta: 1988, hlm. 7.

${ }^{33}$ Ibid., hlm. 99-113.

${ }^{34}$ Op.Cit., hlm. 9.
} 
Modal sosial bukanlah human capital, ia tidak hanya dibangun atas kecenderungan yang tumbuh dalam suatu kelompok. Ia merupakan norma yang dimiliki bersama yang terletak pada kecenderungan yang tumbuh dalam suatu kelompok untuk bersosialisasi sebagai bagian penting dari nilai-nilai yang melekat. Keberhasilan social capital tergantung bagaimana membangun jaringan hubungan sosial.

b. Reciprocity

Dalam konsep modal sosial, asas timbal balik tidak hanya diartikan secara seketika sebagaimana hubungan yang dilandaskan secara kontraktual. Pertukaran kebaikan antara anggota kelompok satu terhadap yang lain tidak selalu dilakukan seketika, melainkan dapat pula sebagai gabungan jangka pendek dan jangka panjang. Semangat untuk saling membantu, dan semangat untuk membalas akan menjadi faktor penentu meningkatnya kualitas sosial capital.

c. Trust

Trust merupakan sikap saling mempercayai di masyarakat yang memungkinkan masyarakat tersebut saling bersatu dengan yang lain memberikan pada penningkatan modal sosial. ${ }^{35}$ Tingkat kepercayaan antara satu anggota masyarakat dengan anggota lainnya, terhadap kelompoknya akan mendukung partisipasi masyarakat dalam rangka membangun kemajuan bersama, sebaliknya kehancuran tingkat kepercayaan tersebut akan menjadi problem sosial yang bisa menghambat pengembangan tujuan-tujuan bersama. Qianhong $\mathrm{Fu}$ membagi tiga tingkatan trust, yaitu: tingkatan individual sebagai kekayaan individu, variable personal dan karakteristik individu, tingkatan relasi sosial, trust dianggap sebagai atribut bersama untuk mencapai tujuan bersama, serta tataran sistem sosial, merupakan nilai masyarakat luas yang tumuh kembangkan serta difasilitasi oleh sistem sosial yang ada.

d. Norma-Norma Sosial

Norma merupakan sekumpulan aturan yang hidup dan diakui sebagai keadah bagi suatu entitas sosial dalam bermasyarakat. Norma-norma sosial biasanya terinstusionalisasi dan mengandung sanksi sosial sehingga dapat mencegah anggota suatu masyarakat untuk menyimpanginya. Norma sosial ini akan sangat berperan dalam mengontrol perilaku masyarakat.

e. Nilai-nilai

Nilai adalah suatu ide yang telah turun temurun dianggap benar dan penting bagi anggota masyarakat. Nilai merupakan takaran yang dapat digunakan untuk mengukur perilaku seseorang pada suatu sistem sosial. Nilai senantiasa memiliki konsekuensi yang ambivalent, dari optik yang satu diangap positif, tapi dari optik yang lain negatif. Nilai senantiasa berperan penting bagi kehidupan manusia dalam bermasyarakat. Biasanya terdapat nilai-nilai tertentu yang mendominasi ide yang berkembang,

${ }^{35}$ Francis Fukuyama, Trust : Social Virtues And Creation Of Prosperity: Trust : Social Virtues And Creation Of Prosperity, Free Press, New York: 1995. 
dominasi tersebut akan mempengaruhi dan membentuk the rule of conduct, the rules of behaviour, dan secara bersama-sama akan membentuk cultural patttern.

\section{f. Tindakan yang Proaktif}

Dalam perspektif social capital, tindakan proaktif memiliki tingkat kualitas yang lebih tinggi apabila dibandingkan dengan partisipasi dalam suatu jaringan. Tindakan proaktif tidak hanya menuntut seseorang untuk terlibat, melainkan juga mencari jalan bagi keterlibatan mererka dalam suatu kegiatan masyarakat.

\section{Peran Masyarakat Sebagai Social Capital}

Peran serta masyarakat jelas sangat menentukan keberhasilan reformasi peradilan. Elemen-elemen masyarakat sipil yang berhimpun dalam lembaga swadaya masyarakat diakui memiliki peran strategis dalam fungsi kontrol terhadap peradilan dan pelaksanaan penegakkan hukum di Indonesia, karena lembaga-lembaga itu didesain khusus untuk memainkan peranperan tertentu. Mereka yang tergabung dalam Lembaga-lembaga Bantuan Hukum misalnya, secara terus menerus memberikan perhatian pada upaya reformasi peradilan dan penegakan hukum. Bahkan banyak diantara mereka yang kemudian membangun kemitraan strategis sebagai partner atau bahkan mengasistensi lembaga-lembaga peradilan.

Ada juga yang berkonsentrasi dalam pemantauan pembentukan perundang-undangan, pemberantasan korupsi dan lain-lain. Bahkan peran serta itu belakangan telah diakui urgensi dan signifikasinya. Kelompok masyarakat sipil lainnya adalah kalangan perguruan tinggi. Independensi para ilmuwan dan aktivis yang berhimpun dalam pusat-pusat studi telah secara nyata memberikan kontribusi bagi dunia peradilan dan penegakan hukum.Peran serta masyarakat yang paling banyak dilakukan pertama, adalah melalui kerja-kerja pemantauan dibidang peradilan dan penegakan hukum.

Pemantauan memiliki arti penting dalam rangka memastikan agar setiap kehendak politik yang terakumulasi dalam suatu kebijakan negara diorientasikan sepenuh-penuhnya untuk memberikan keadilan bagi semua orang ${ }^{36}$. Kerja pemantauan diharapkan mampu menghimpun fakta-fakta yang baik maupun yang kurang baik dari segi proses penyusunan, substansi, pelaksanaan dan penegakan maupun dampak dari berbagai proses-proses peradilan dan penegakan hukum. Dalam sistem demokrasi, kerja pemantauan juga merupakan bentuk kontrol publik untuk menyeimbangkan kekuatan antara penyelenggara negara atau pemerintahan dengan publik di daerah itu.

Prinsip checks and balances, sebagai salah satu prinsip demokrasi, dapat dijalankan. Kerja-kerja pemantauan selama ini banyak dilakukan oleh kelompok elemen sipil yang tergabung di dalam lembaga-lembaga swadaya masyarakat. Mereka berhimpun dan mengkonsentrasikan diri pada upaya-upaya memastikan proses peradilan berjalan secara adil. Pemantauan yang dilakukan oleh elemen masyarakat sipil ini merupakan jawaban atas tidak adanya akuntabilitas yang terlembagakan pada lembaga-lembaga peradilan. Sekalipun pengawasan internal di tubuh lembaga peradilan sudah tersedia, kepercayaan publik belum

\footnotetext{
${ }^{36}$ Din Syamsudin, Peran Serta Elemen Masyarakat Sipil dalam Mendorong Proses Reformasi Peradilan dan Penegakan Hukum, Bunga Rampai Komisi Yudisial, Jakarta: hlm. 156.
} 
sepenuhnya bisa tumbuh akibat minusnya penindakan jika pengawasan menemukan abuses yang dilakukan oleh para penegak hukum.

Untuk memaksimalkan upaya reformasi peradilan itulah maka publik menginisiasi praktik-praktik eksaminasi yang disebut dengan eksaminasi publik. Tujuan eksaminasi secara umum adalah untuk mengetahui, sejauh mana pertimbangan hukum dari hakim yang memutus perkara tersebut berkesesuaian dengan prinsip-prinsip hukum dan prosedur hukum acara dengan benar, serta menakar sejauh mana sebuah putusan telah menyentuh rasa keadilan masyarakat. Sasaran utama dari kegiatan eksaminasi ini adalah mendorong para hakim agar membuat putusan dengan pertimbangan yang baik dan profesional.

Catatan yang dapat diajukan dalam memandang peran serta masyarakat sipil dalam reformasi peradilan dan penegakan hukum ini, seringkali ekpektasi publik tidak terpenuhi oleh lembaga-lembaga peradilan. Peran serta kemudian menjadi bagian yang dianggap tidak menarik sebagian elemen masyarakat sipil. Keberbedaan pendekatan antar elemen juga sering menjadikan pilihan strategi yang berbeda. Semestinya sinergi harus bisa dibangun, sehingga meskipun dengan pendekatan dan strategi yang berbeda, tetap bisa mengarah sasaran yang sama, yakni perbaikan peradilan dan penegakan hukum. Oleh karenanya, masyarakat sebagai salah satu modal sosial (social capital) memiliki peranan penting dalam upaya mereformasi lembaga peradilan di Indonesia.

\section{Social Capital Dalam Membentuk Peradilan Modern Berbasis Kepekaan Sosial}

Di dalam bidang politik, penelitian yang tersohor dari Putnam di Italia (making democracy work), mencoba melihat bangunan institusi administrasi local yang didirikan dengan sumber modal sosial yang berbeda menghasilkan kinerja yang berbeda pula. Dalam penelitiaannya ditemukan bahwa lembaga-lembaga administrasi serupa yang didirikan dalam konteks sosial, ekonomi, politik dan budaya yang berbeda menghasilkan kinerja pemerintahan yang juga berbeda. Beberapa di antara pemerintahan tersebut inefesien, lamban, dan korup, sedangkan yang lainnya menunjukan kinerja yang efektif, inovatif, dan dapat dipertanggungjawabkan. Putnam menyimpulkan, "kunci atas perbedaan kinerja publik ini adalah perbedaan sumber modal sosial daerah-daerah tersebut, di samping norma keterlibatan warga negara yang kuat.

Modal sosial yang positif atau tinggi dalam suatu komunitas pemerintahan, akan membawa dampak pada tingginya partisipasi masyarakat sipil dalam berbagai bentuk. Dari berbagai kajian yang dilakukan selama ini membuktikan bahwa di tengah masyarakat yang memiliki modal sosial yang positif/tinggi terdapat beragam determinan yang memungkinkan negara dapat berfungsi secara lebih efektif dan memiliki legitimasi. Bahkan modal sosial tidak hanya dapat digunakan dalam ketiga bidang yang disebutkan di atas. Tom schuller menggaris bawahi luasnya cakupan modal sosial dalam hampir semua fenomena sosial. Tom schuller mengelaborasinya sebagai berikut:

More economistic interpretations give greater emphasis to the institutions and rules governing economic transactions, at micro and macro levels. 
Social capital has been deployed to explain a wide range of social phenomena,

including general economic performance, levels of crime and disorder,

immigrant employment and health trends. ${ }^{37}$

Meskipun pendapat diatas menggambarkan modal sosial memiliki aspek positif yang dapat memberikan sumbangan nyata bagi bidang sosial lainnya, tetapi tidak dapat disangkal juga bahwa modal sosial memiliki aspek negatif yang dapat saja merusak tatanan masyarakat dalam konteks yang lebih besar. Modal sosial merupakan sebuah kebaikan privat yang diliputi juga oleh eksternalitas, baik positif maupun negatif. ${ }^{38}$

Di dalam demokratisasi pemerintahan, modal sosial yang negatif manifestasinya muncul dalam 3 (tiga) bentuk, yakni: eksklusivitas, korupsi dan penindasan ${ }^{39}$. Eksklusivitas ditandai oleh berlakunya kondisi batas (berdasarkan jenis kelamin, umur, kasta, etnis, kelas dan pendapatan) yang lalu mengasingkan kelompok yang tidak termasuk dalam persyaratan tersebut. Korupsi (dan berbagai bentuk perlindungan kronisme, nepotisme dan penyalahgunaan wewenang) ditandai oleh dominannya dukungan pada kepentingan kelompok tertentu. Sedangkan penindasan, lebih ditandai oleh adanya halangan bagi anggota komunitas untuk melakukan pilihan independen, dan atau dalam menentukan pilihan untuk berpartisipasi secara aktif dalam kehidupan komunitas.

Tay mencatat paling tidak terdapat tujuh aspek negatif dari akibat modal sosial rendah di era transisi, yaitu:

a. dalam masa transisi, nilai-nilai sangatlah lemah. Sementara praktik-praktik lama dalam banyak hal sudah didiskreditkan, nilai-nilai baru masih belum mapan”. Diduga, hal ini terjadi karena terkurasnya nilai positif modal sosial selama pemerintahan otoriter Soeharto terutama tumbuh suburnya praktik-praktik korupsi, kolusi dan nepotisme;

b. pemerintah ditingkat nasional lebih tidak dipercaya daripada pemerintahan daerah;

c. tingkat minat atau keterlibatan masyarakat sebagai bentuk partisipasi politik masih rendah;

d. berkurangnya solidaritas nasional atau minimnya perasaan identitas bersama. Situasi ini ditandai sebagai situasi “...peta politik Indonesia ditandai dengan banyaknya jurang yang memisahkan daerah dan kelompok, manifestasi dari sifat ekslusif, ketidakpercayaan, dan hubungan yang antagonistis....merupakan ciri utama dari modal sosial yang negatif'.

e. saluran informasi masih dibuat sesuai kebutuhan penguasa (personalized);

f. kondisi batas di Indonesia tidaklah membantu untuk pendekatan inklusif dalam pemecahan masalah.

\footnotetext{
${ }^{37}$ Tom schuller, The Complementary Roles of Human and Social Capital, Brickbek Collage-University of London, London, 2001, hlm. 4.

${ }^{38}$ Francis Fukuyama, Social Capital and, ... Op.cit.

${ }^{39}$ Tay Keong Tan, 2001. Op.Cit., hlm. 64.
} 
Mengenai modal sosial dan lembaga legislatif di Indonesia, Tay ${ }^{40}$ mengemukakan masih dominannya aspek negatif modal sosial. Pertama, "di dalam parlemen, struktur kewenangan relatif hirarkis. Pengambilan keputusan dan penetapan agenda lebih berat pada pemimpin fraksi. Kecenderungan pengambilan keputusan yang dikontrol elit tersebut, kemudian diperburuk oleh kewenangan partai politik yang mempunyai kemampuan me"recall" wakil rakyat yang tidak mengikuti garis partai". Kedua, pada tingkat nasional, "informasi penting mengalir melalui jalur tertutup yang seringkali bersifat pribadi; ini menghambat beberapa prinsip utama dalam demokrasi" yakni "demokrasi menghendaki agar informasi terbuka bagi publik...." dan, "rakyat harus memiliki informasi untuk berpartisipasi dengan para pemimpin dalam menetapkan agenda, perumusan kebijakan, dan implementasi”. Ketiga, "kondisi batas yang memisahkan parlemen dari bangsa cukup ketat", hal mana ditandai oleh ruang publik di parlemen yang minimal.

Sebaliknya apabila modal sosial tinggi, ia merupakan energi pembangunan yang sangat dahsyat dalam berbagai lini. Masing-masing entitas sosial memiliki tidak saja tipologi, melainkan juga konfigurasi nilai dan norma yang sangat menentukan derajat kerekatan sosial dan kolaborasi sosial dalam masyarakat. ${ }^{41}$ maka masyarakat akan memiliki respon terhadap setiap kebijakan pemerintah, termasuk kebijakan penegakan hukum. Berfikir komperhensif dalam formulasi, aplikasi maupun implementasi kebijakan merupakan reorientasi berfikir menuju penegakan hukum yang progresif.

Di negeri yang besar seperti Indonesia, yang hidup dengan kompleksitas persoalan dan pluralitas realitas sosial, dimensi social capital hampir kurang mendapat perhatian dalam pemikiran pembangunan bangsa. Modal sosial merupakan modal yang sangat penting dalam meletakkan fungsi dan memperkuat kehidupan masyarakat modern. ${ }^{42}$ Ketidakadilan yang dirasakan masyarakat terumata masyarakat kelompok bawah dan berbagai penyimpangan yang terjadi diberbagai belahan bumi, terutama di negara-negara berkembang, Asia, Afrika, dan Amerika Latin salah satu determinan utamanya adalah kerdilnya modal sosial yang tumbuh di tengah masyarakat. ${ }^{43}$ Modal sosial menjadi energi cadangan yang barangkali belum disalurkan guna membrantas tindakan-tindakan koruptif dengan berdasarkan pada kebersamaan, mobilitas ide, dan dan sikap saling menguntungkan.

Faktor kultural, khususnya modal sosial menempati posisi yang sangat periferal sebagai faktor yang menentukan kualitas manusia. ${ }^{44}$ Penegakan hukum tidak akan lepas dari kualitas ketiga sub sitemnya, yaitu: legal subtance, legal culture dan legal structure. Kualitas manusia menentukan berhasil tidaknya penegakan hukum dari segi budaya hukum dan struktur hukum itu sendiri. Untuk selanjutnya dapat dikatakan, rendahnya modal sosial yang dimiliki oleh suatu bangsa, akan mempengaruhi berhasil tidaknya upaya penegakan hukum yang dilakukan, termasuk juga dalam pemberantasan tindak pidana korupsi.

\footnotetext{
${ }^{40}$ Ibid., hlm. 80-81.

${ }^{41}$ Jousairi Hasbullah, Social Capital (Menuju Keunggulan Budaya Manusia Indonesia), MR-United Press, Jakarta: 2006, hlm. vi.

${ }^{42}$ Francis Fukuyama, The end Social Capital and Civil Society, Institue of Public Policy-Ceorge Mason University: 1998.

${ }^{43}$ Op.Cit., hlm. vi.

${ }^{44}$ Francis Fukuyama, Social Capital and Development: The Coming Agenda, SAIS Review XXX (1), 2002, hlm. 23-27.
} 
Modal sosial juga memiliki keterkaitan erat dengan efektifitas pemerintahan. Modal sosial yang tinggi akan membawa dampak pada tingginya partisipasi masyarakat sipil dalam berbagai bentuknya. ${ }^{45}$ Masyarakat yang memiliki modal sosial yang tinggi akan memiliki sikap yang harmonis serta menunjang program-program negara dalam masyarakat, tidak terkecuali program pemberantasan korupsi. Partisipasi aktif masyarakat yang memiliki modal sosial yang tinggi dalam suatu masyarakat akan dapat meminimalisir berbagai bentuk tindakan koruptif. Dalam masyarakat yang memiliki tingkat modal sosial yang tinggi, maka partipasi masyarakat dalam pembangunan tidak hanya bersifat pasif, melainkan aktif, bahkan proaktif.

Negara dan modal sosial sebenarnya memiliki hubungan fungsional yang saling mendukung satu sama lain. Disatu sisi, semakin tinggi tingkat modal sosial, maka semakin tinggi pula efektifitas pemerintahan. Sebaliknya, negara dengan programnya juga dapat berperan dalam memperkuat modal sosial warganya. Negara dapat menciptakan suasana yang kondusif bagi tumbuh kembangnya kelompok-kelompok sosial dengan modal sosial yang kuat. Pemerintah pula yang paling memiliki kemungkinan untuk menyediakan infrastruktur pendorong bagi tumbuhnya masyarakat sipil yang memiliki modal sosial yang tinggi. ${ }^{46}$

Terkait hal itu maka dalam kerangka reformasi peradilan, selain kecerdasan secara intelektual, emosional, dan spiritual, kecerdasan secara sosial, maka kepekaan sosial menjadi salah satu elemen penting yang pada gilirannya akan mewarnai secara kuat karakter para penegak keadilan di Indonesia. Aparat peradilan yang cerdas secara intelektual, emosional, spritiual juga secara sosial akan menjadi sosok-sosok unggul dan profesional dalam menimplementasikan berbagai nilai dasar peradilan modern yang merupakan kerangka fundamental peradilan yang excellent. Aparatur perradilan yang cerdas baik secara intelektual, emosional, spiritual dan bahkan sosial akan tampil sebagai pejabat yang terampil, cerdas, jujur, amanh, berdisipilin tinggi, memiliki integritas, profesional, kreatif, peduli, bahkan menunjukkan progresivitasnya dalam menghadapi dinamika massa dan masyarakat. Semua karakter ini selanjutnya akan membuat program modernisasi peradilan menuju lembaga yang modern dan transparan bukan menjadikan hal tersebut sebagai target yang sulit dicapai.

\section{Fungsionalisasi Social Capital Pada Peradilan Di Indonesia}

Parsons mendefinisikan fungsi sebagai segala kegiatan yang diarahkan kepada memenuhi kebutuhan atau kebutuhan-kebutuhan dari sebuah sistem ${ }^{47}$. Modal sosial adalah seperangkat perkumpulan horisontal yang terdiri atas kepercayaan, nilai dan norma-norma, jaringanjaringan sosial, dan struktur otoritas yang berfungsi memfasilitasi kerja sama dalam komunitas sosial. Dengan mengacu pada teori modal sosial dari Francis Fukuyama, maka kunci utama modal sosial yang perlu difungsionalisasikan mencakupi: (1) kepercayaan, (2) nilai dan norma-norma, (3) jaringan-jaringan sosial, dan (4) struktur otoritas.

Modal sosial dapat menimbulkan dampak yang positif dan negatif. Dampak positif ini akan muncul apabila modal sosial tinggi menumbuhkan kepercayaan pada pemerintah

\footnotetext{
${ }^{45}$ Robert Putnam dalam Jousairi Hasbullah, Social Capital (Menuju Keunggulan Budaya Manusia Indonesia), MR-United Press, Jakarta: 2006, hlm. 44.

${ }^{46}$ Ibid., hlm. 45

${ }^{47}$ Bernard Raho, Teori Sosiologi Modern, Prestasi Pustaka, Jakarta:2007.
} 
termasuk upaya penegakan hukum dan reformasi peradilan. Di sisi lain adanya pengaruh luar seperti globalisasi, kebijakan pemerintah, dan nilai-nilai universal dimungkinkan tumbuhnya kohesi kelompok masyarakat yang solid, jaringan sosial yang luas, tingginya sikap toleran, kuatnya ketahan sosial, kontribusi yang positif terhadap pembangunan. Sebaliknya apabila modal sosial itu rendah (berkembang secara eksklusif), dapat menimbulkan eksklusivisme sosial, dominannya sikap intoleran, hancurnya kesatuan, merajalelanya ketidakadilan atas nama kelompok, munculnya sikap menentang perubahan, dan menghambat pembangunan. Untuk itulah perlu adanya kegiatan-kegiatan yang dapat meningkatkan modal sosial. Untuk meningkatkan modal sosial pada upaya penegakan hukum dan reformasi lembaga peradilan di Indonesia, dapat melalui pendekatan moralistik (keimanan), dan pendekatan edukatif. Pendekatan moralistik dan keimanan merupakan rambu-rambu pembatas untuk meluruskan langkah para pejabat publik khususnya penegak hukum untuk memperkuat integritas dalam pelaksanaan tugas dan kewenangannya. Pendekatan edukatif berfungsi menggerakkan dan meningkatkan daya nalar masyarakat sehingga mempunyai pemahaman yang komprehensif, dan berfungsi membangun kultur atau budaya masyarakat yang mengutuk segala bentuk kejahatan dan ketidakadilan.

Pendekatan moralistik dan keimanan dalam membangun keterpercayaan masyarakat terhadap penegakan hukum dan reformasi lembaga peradilan dilakukan melalui keteladan dari para penegak hukum. Pembangunan institusi penegak hukum tidak dapat dilepas-pisahkan dari konteks pembangunan hukum nasional, yang mengedepankan reformasi hukum sebagai bahan integral dari proses demokratisasi dalam kehidupan bermasyarakat, berbangsa, dan bernegara. Acuan dalam pembangunan institusi penegak hukum ini, melalui upaya reformasi hukum, hendaknya didasarkan kepada kepentingan ke depan bangsa dan negara, bukan diperuntukkan kepada kepentingan kelompok atau kekuasaan yang bersifat sektoral. Artinya, antara lain, pembangunan institusi penegak hukum tersebut di masa depan hendaknya, pada hakikatnya mewujudkan suatu institusi yang mandiri, independen serta didukung oleh aparatnya yang profesional dan proporsional serta memiliki integritas sesuai kehendak perkembangan masyarakat yang sangat rentan perubahan.

Kurangnya independensi institusi penegak hukum, membawa akibat besar dalam sistem hukum. Intervensi terhadap kekuasaan yudikatif misalnya, telah mengakibatkan terjadinya partialitas dalam berbagai putusan, walaupun hal seperti ini menyalahi prinsip-prinsip impartialitas dalam sistem peradilan. Akumulasi terjadinya putusan-putusan yang meninggalkan prinsip impartialitas dalam jangka panjang telah berperan terhadap terjadinya degradasi kepercayaan masyarakat kepada sistem hukum karena tersamarnya kepastian hukum.

Independansi dan akuntabilitas kelembagaan hukum merupakan dua hal yang tidak dapat dipisahkan ini bagaikan dua sisi uang logam. Oleh karena itu, independensi lembaga hukum harus disertai dengan akuntabilitas. Namun demikian dalam praktik, pengaturan tentang akuntabilitas lembaga hukum tidak dilakukan dengan jelas, baik kepada siapa atau lembaga mana ia harus bertanggung jawab maupun tata cara bagaimana yang harus dilakukan untuk memberikan pertanggungjawabannya. Hal yang demikian telah memberikan kesan tiadanya transparansi di dalam semua proses hukum. 
Sumber daya manusia di bidang hukum, secara umum kualitas sumber daya manusia penegak hukum masih perlu peningkatan, termasuk dalam hal memahami dan berperilaku responsif gender. Rendahnya kualitas sumber daya manusia di bidang hukum juga tidak terlepas dari belum mantapnya sistem pendidikan hukum yang ada. Apalagi sistem, seleksi serta kebijakan pengembangan SDM di bidang hukum yang diterapkan ternyata tidak menghasilkan SDM yang berkualitas. Disamping itu, sinyalemen tentang kurangnya integritas dari para pelaku hukum juga sangat memprihatinkan. Bahkan ada sementara pihak yang justru mengambil keuntungan dari situasi yang ada. Ini semua berpengaruh besar terhadap memudarnya supremasi hukum serta semakin menambah derajat ketidakpercayaan masyarakat terhadap sistem hukum yang ada. Karena dalam rekruitmen penegak hukum perlu memperhatikan aspek integritas moral yang mendukung penegakan hukum.

Keteladan lain yang dapat meningkatkan kepercayaan masyarakat adalah melalui pelayanan publik satu atap. Apa yang telah dilakukan oleh Pemerintah Kabupaten Sragen, barangkali dapat dijadikan model pelayanan publik sehingga menumbuhkan tingkat keterpercayaan masyarakat terhadap pemerintah. Dengan pelayanan publik satu atap yang memadahi dan memberikan kepusasan kepada masyarakat pada akhirnya dapat berkontribusi dalam menujmbuhkan partisipasi masayarakat dalam pembangunan.

Pelayanan publik satu atap ini di sisi lain juga dapat membangun jaringan komunikasi, sehingga kerjasama antar warga terjalin dengan baik. Keterbukaan pelayanan publik ini akan mendorong masyarakat percaya pada pemerintah dan masyarakat lebih berani untuk mengungkapkan ketidakbenaran dan ketidakjujuran hingga menjadi terdepan dalam mengusung keadilan dalam masyarakat, untuk itu dalam jangka panjang keadilan yang hakiki dapat ditegakkan.

Pembinaan satu atap seperti yang sekarang dilaksanakan oleh Mahkamah Agung merupakan upaya untuk mewujudkan kemandirian kekuasaan kehakiman dan menciptakan putusan pengadilan yang tidak memihak (impartial). Situasi itu menjadikan Cetak biru (blueprint) yang dibuat dalam rangka mendukung Mahkamah Agung untuk melaksanakan pembinaan satu atap lembaga peradilan telah dibuat secara komprehensif. Ini dimaksudkan untuk menetapkan langkah-langkah prioritas dalam pembenahan lembaga peradilan. Apabila kegiatan ini dilakukan secara konsisten diharapkan dapat menumbuhkan keterpercayaan masyarakat dalam upaya penegakan hukum.

Pendekatan edukatif dilakukan untuk memfungsionalisaikan nilai dan norma yang telah ada dalam masyarakat diarahkan untuk membangun kultur atau budaya hukum masyarakat yang mengutuk segala bentuk ketidak adilan, ketidakjujuran dan kejahatan. Seperti telah disebutkan di atas bahwa upaya penegakan hukum dan reformasi lembaga peradilan perlu dilakukan secara komprehensif. Salah satu upaya yang dilakukan yaitu melalui pendidikan edukatif. Membangun budaya hukum masyarakat tidak terlepas dari proses pendidikan moral.

Salah satu pendidikan moral yang penting dalam penegakan hukum dan reformasi peradilan adalah moral kejujuran. Karena ketidakadilan sebenarnya timbul oleh suatu keberpihakan keadaan atau perbuatan seseorang yang tidak tepat. Nilai moral kejujuran kalau 
dikaji sebenarnya telah ada di dalam masyarakat sebagai modal sosial, agar nilai dalam modal sosial ini tinggi maka perlu dilakukan upaya pendidikan moral.

\section{PENUTUP}

\section{Kesimpulan}

Dari uraian di atas maka dapat disimpulkan bahwa dalam masa transisi (demokrasi) ini dapat dikatakan penerapan nilai-nilai sebagai modal sosial di Indonesia masih sangat lemah. Berbagai upaya yang dilakukan selama ini dalam penegakkan hukum di Indonesia belum menunjukkan keberpihakannya pada rakyat di kelompok bawah. Hal tersebut terjadi karena minimnya kepekaan sosial yang merupakan salah satu social capital terpenting dalam pembentukan karakter penegak hukum.

\section{Saran}

Pentingnya menumbuhkan kepekaan sosial bagi para penegak hukum ini bertujuan guna melakukan reformasi birokrasi dengan selalu melakukan upaya mereformasi lembaga peradilan Indonesia. Maka keadilan akan fokus dalam menyelesaikan putusan yang memiliki keadilan bagi masyarakat, dalam kehidupan peradilan dengan konsep jangka panjang, yaitu melakukan penerapan modal sosial di lembaga peradilan harus diupayakan dan diwujudkan mulai saat ini tanpa menunggu berapa banyak lagi rasa ketidakadilan yang dialami oleh masyakarakat Indonesia.

\section{DAFTAR PUSTAKA}

\section{Buku}

Bernard Raho, Teori Sosiologi Modern. Prestasi Pustaka, Jakarta, 2007.

Budi Gunawan, Koloni Keadilan; Kumpulan Analisis di Majalah Forum, Forum Media Utama. Jakarta, 2006.

Christian Grootaert, Social Capital, Hauseholf Welfare, and Proverty in Indonesia, Policy Research Working Paper 2148, World Bank, Washington D.C., 1999.

Darmaputera, Eka. 1988. Pancasila Identitas dan Modernitas: Tinjauan Etis dan Budaya. BPK Gunung Mulia. Jakarta.

Din Syamsyudin, Peran Serta Elemen Masyarakat Sipil dalam Mendorong Proses Reformasi Peradilan dan Penegakan Hukum (Komisi Yudisial dan Reformasi Peradilan, Bunga Rampai), Komisi Yudisial, Jakarta, 2007.

Fukuyama, Francis, Social Capital and Development: The Coming Agenda. SAIS Review XXX(1), 2002.

, The Great Disruption: Hak Asasi Manusia dan Rekonstruksi Tatanan Sosial, Qalam, Yogyakarta, 2002.

, The end Social Capital and Civil Society. Institue of Public Policy. Ceorge Mason University, 1998.

Jonathan Turner, The Structure of Sociological Theory, ILL: The Dorsey Press. Chicago, 1986.

Jousairi Hasbullah, Social Capital (Menuju Keunggulan Budaya Manusia Indonesia), MRUnited Press. Jakarta, 2006. 
Pierre Bourdieu, The Forms of Capital, Handbook of Theory and Research for the Sociology of Education, New York-Greenwood, 1986.

Robert D. Putnam, The Strange Disappearance of Civic American', policy, autumn, 1996. , Making Democracy Work: Civic Traditions in Modern Italy, Princeton University Press, Princeton, 1993 , The Prosperous Community: Social Capital and Public Life. The American Prospect, Spring, 1993a.

Robert N. Bellah dan Religi Tokugawa, Akar-akar Budaya Jepang, terjemahan W. Hafidz. Karti Sarana \& Gramedia, Jakarta, 2008.

Salman, IESQ Based Court Modernization: Menuju Peradilan Modern Berbasis Kecerdasan Intelektual, Emosional, dan Spiritual, Pengadilan Agama Cilegon, Banten, 2009.

Sankey, Lord, dalam McLachlin, Beverly. 2003. Court, Transparency, and Public Confidence to the Better Administration of Justice, Makalah 16 April 2003.

Tay Keong Tan, Modal Sosial dan Lembaga-Lembaga Legislatif, dalam, Panduan Parlemen Indonesia. Yayasan Api, Jakarta, 2001.

Theodore M. Steeman, Religious Pluralism and National Integration, Disertation. Harvard University, Massachussets, 1987.

Tom schuller, The Complementary Roles of Human and Social Capital, Brickbek CollageUniversity of London, London, 2001.

World Bank, The Initiative on Defining, Monitoring, and Measuring Social Capital, Overview and Programme Description, Working paper, No. 1. http://www.worldbank.org/poverty/ scapital/wkrppr/sciwpl.pdf, diakses pada tanggal 17 Januari 2018

\section{Jurnal}

James S. Coleman, Social capital in the Creation of Human Capital, American Journal of Sociology, vol. 94, 1998

Robert D. Putnam, Foreword, housing Policy Debate, No. 1, Vol. 9, 1998

\section{Internet}

http://www.ti.or.id, diakses pada tanggal 17 Nopember 2017

http://ahmadrifan.wordpress.com diakses pada tanggal 16 Januari 2018 